\title{
Thermogravimetric Study of Napier Grass in Inert and Oxidative Atmospheres Conditions
}

\author{
Tan Hong Boon, ${ }^{*}$ Abdul Raheem, ${ }^{2}$ Wan Azlina Wan Abdul Karim Ghani, ${ }^{1}$ \\ Siti Aslina Hussain ${ }^{1}$ and Denny Ng Kok Sum ${ }^{3}$ \\ ${ }^{1}$ Department of Chemical and Environmental Engineering, Faculty of Engineering, \\ Universiti Putra Malaysia, 43400 UPM Serdang, Malaysia \\ ${ }^{2}$ School of Environment, Tsinghua University, Beijing, 100084, China \\ ${ }^{3}$ Department of Chemical and Environmental Engineering, Centre of Sustainable Palm \\ Oil Research (CESPOR), University of Nottingham Malaysia, Broga Road, \\ 43500 Semenyih, Selangor, Malaysia \\ *Corresponding author: hboonn90@gmail.com
}

Published online: 15 February 2017

To cite this article: Tan, H. B. et al. (2017). Thermogravimetric study of napier grass in inert and oxidative atmospheres conditions. J. Phys. Sci., 28(Supp. 1), 155-169, https://doi.org/10.21315/jps2017.28.s1.10

To link to this article: https://doi.org/10.21315/jps2017.28.s1.10

\begin{abstract}
Since the industrialisation of Malaysia, the energy demand which mainly relied on fossil fuels has risen continuously. Therefore, all parties including the government, academic society and communities have explored alternative fuel resources to improve the reliability and security of energy supply to meet the future energy. In recent years, biomass has been identified as one of the most promising renewable energy resources compared to hydro, solar, wind, etc. It is projected that energy crops could potentially supply around 200-400 EJ/year in Malaysia at a competitive cost by 2050. Perennial grass is one type of energy crop that could address the above mentioned challenge. In this work, Napier grass (NG) is chosen as the subject due to its desirable characteristics (availability, high growth rates, carbon neutrality and high volatility). In order to investigate the feasibility of $N G$ for heat and power application, the thermal decomposition characteristics, reactivity, and kinetic of $N G$ needed were tested via thermogravimetric analysis (TGA) under inert (nitrogen) and air atmosphere conditions, respectively. The results indicated that $N G$ biomass has great potential as sustainable energy fuel source for energy generation via gasification process.
\end{abstract}

Keywords: Napier grass, thermogravimetric analysis (TGA), kinetics, oxidative atmospheres, alternative fuel 


\section{INTRODUCTION}

Energy consumption has risen continuously and soon Malaysia will be facing shortage of fossil fuels (primary energy supply) due to industrialisation. ${ }^{1}$ It is forecast that in 2004-2030, the gross domestic product (GDP) in Malaysia will increase to $4.6 \%$ whereas the energy demand can grow up to $216 \mathrm{TWh}$ in $2030 .{ }^{2,3}$ Hence, it is inevitable that all parties (government, academic society and communities) explore new alternative fuel resources to ensure the reliability and security of energy supply for to meet the future energy demands.

Energy crop has attracted a great interest from the research community compared to others renewable energy resources (hydro, solar, wind, etc.). According to Hlavsova et al., it is expected that energy crops could potentially supply around $200-400 \mathrm{EJ} /$ year at a competitive cost by $2050 .{ }^{4}$ Conto et al. asserted that perennial grasses could contribute significantly to mitigate energy insecurity as well as climate change in the near future. ${ }^{5}$ Napier grass (NG) or Pennisetum purpureum is one of the most promising perennial grasses which can produce high biomass yield (average 40 tons yield per hectare per annum) as compared to other energy grasses such as miscanthus and switchgrass. ${ }^{6}$ In addition, it follows conventional farming practice with lower establishment. Besides, it also has strong resistance to the weeds and diseases which allow NG to survive much longer. In addition, it can produce high biomass yield which equals to 100 barrels of oil energy equivalent per hectare. Furthermore, NG can be harvested up to four times per year. Note that the energy output to energy input ratio of NG is reported to be $25: 1$, thus it is considered the best potential energy crop for bio-energy production. ${ }^{7}$

NG is a herbaceous plant that contains a high percentage of lignocellulosic material which is suited for thermo-chemical conversion. Biomass thermo-chemical conversion is a proven technology which converts biomass to bio-fuel. Gasification is one of the thermo-chemical conversion processes that is commonly used to transform bio-fuel due to its simplicity, flexibility, efficiency and less pollutants emission. ${ }^{8}$ Substantial research on biomass gasification has been performed lately to better understand the effect of temperature, equivalence ratio, particle size, heating rate, etc. on the gasification performance. For example, Raheem et al. studied the effect of gasification temperature $\left(700^{\circ} \mathrm{C}, 800^{\circ} \mathrm{C}\right.$ and $\left.900^{\circ} \mathrm{C}\right)$, microalgal loading $(5,10$ and $20 \mathrm{~g})$ and heating rate $\left(5^{\circ} \mathrm{C} / \mathrm{min}, 10^{\circ} \mathrm{C} / \mathrm{min}\right.$ and $\left.20^{\circ} \mathrm{C} / \mathrm{min}\right)$ on Chlorella vulgaris biomass. ${ }^{9}$ The maximum $\mathrm{H}_{2}$ production was found at $800^{\circ} \mathrm{C}$ temperature with a biomass loading of $0.5 \mathrm{~g}$. Besides, no significant effect of heating rate was observed on $\mathrm{H}_{2}$ production. Xue et al. studied the effect of equivalence ratio (ER) $(0.234-0.372)$ and bed temperature $\left(645^{\circ} \mathrm{C}-726^{\circ} \mathrm{C}\right)$ on miscanthus $\mathrm{x}$ giganteus. ${ }^{10}$ No sign of agglomeration was found in the ER $(0.262)$ and temperatures $\left(645^{\circ} \mathrm{C}\right)$. 
Besides, the higher heating value $\left(6.27 \mathrm{MJ} / \mathrm{m}^{3}\right)$ of product gas, gas yield $(1.65$ $\mathrm{Nm}^{3} / \mathrm{kg}$ ), carbon conversion efficiency $(94.81 \%)$ and hot gasification efficiency $(78.76 \%)$ were determined in abovementioned operating condition. Therefore, proper understanding on the thermal degradation of biomass is very important to evaluate their potential of utilisation of biomass via gasification technology. Thermogravimetric analysis (TGA) is a well-established technique which is widely used to evaluate the performance of thermal decomposition behaviour of biomasses. ${ }^{11}$ Besides, TGA also can determine biomass composition, reaction order and kinetic constant. ${ }^{12}$ Recently, Raheem et al. performed TGA of chlorella vulgaris under $\mathrm{N}_{2}$ and air atmosphere condition with different heating rates to investigate the thermal degradation behaviour. ${ }^{9}$ Kok et al. conducted TGA of miscanthus, poplar wood and rice husk biomasses to study the combustion behaviour. ${ }^{13}$ Shen et al. performed TGA of wood samples (pine, aspens, birch and oak) under oxidative environment at different heating rates to analyse the kinetics of biomass decomposition. ${ }^{11}$ Gao et al. performed TGA of tobacco residues under nitrogen atmospheric condition with $10^{\circ} \mathrm{C} / \mathrm{min}$ to determine the pyrolytic characteristics. ${ }^{14}$

The objective of present study is to investigate the thermogravimetric characteristic of the NG which was provided by Crops for the Future Research Centre (CFFRC) via TGA under an oxidative (air) and inert $\left(\mathrm{N}_{2}\right)$ atmospheres with different heating rates $\left(5^{\circ} \mathrm{C} / \mathrm{min}, 10^{\circ} \mathrm{C} / \mathrm{min}\right.$ and $\left.20^{\circ} \mathrm{C} / \mathrm{min}\right) . \mathrm{N}_{2}$ is an inert gas which offers an inert environment and commonly acts as a heating agent for pyrolytic reaction. It does not reactively promote the reaction. In contrast, air atmosphere provokes gasification reaction due to presence of oxygen. Therefore, TG-DTG curves obtained could provide better understanding of the dissimilarities in the NG biomass characteristics with regard to the heating behaviour and the rate of mass loss under $\mathrm{N}_{2}$ and air atmosphere with different heating rate. Furthermore, thermogram interpretation and kinetic analysis on the biomass characteristic are indispensable to delve into the thermochemical conversion efficiency for bioenergy production purpose.

\section{EXPERIMENTAL}

The mature NG was obtained from the plantation site at CFFRC, Semenyih, Selangor, Malaysia. The biomass was dried at $105^{\circ} \mathrm{C}$ by an oven based on BS EN 12048 standard. The dried NG biomass was then shredded into particle sizes of 0.2 and $2 \mathrm{~mm}$ via Retsch rotor beater mill and kept in air tight plastic bags for ultimate and proximate analysis.

Thermogravimetric analyser (TGA/SDTA851, Mettler Toledo, USA) was used to study the non-isothermal gasification and pyrolysis of NG biomass. $20 \mathrm{mg}$ of dried 
biomass powder was placed in an alumina crucible and put into the TGA furnace. The NG sample was continuously heated from ambient temperature to $1,000^{\circ} \mathrm{C}$ under $\mathrm{N}_{2}$ and air atmosphere conditions at three different heating rates $\left(5^{\circ} \mathrm{C} / \mathrm{min}\right.$, $10^{\circ} \mathrm{C} / \mathrm{min}$ and $20^{\circ} \mathrm{C} / \mathrm{min}$ ). The volume flow of $\mathrm{N}_{2}$ and air was $25 \mathrm{~mL} / \mathrm{min}$. The proximate analysis (i.e., moisture, volatile matter, fixed carbon and ash content) of NG biomass were established by means of a TGA analysis.

LECO TruSpec CHNS628 elemental analyser was used to determine the ultimate analysis based on ASTM D-5291 method. Higher Heating Value (HHV) of NG biomass was determined via Parr 6100 oxygen bomb calorimeter following BS EN 14918. The structural analysis of NG was determined according to the procedure outlined in NREL/TP-510-42618.7

\subsection{Kinetic Study of NG Biomass}

Kinetic analysis provides a better understanding about the reaction mechanism and rate of reaction. The model free fitting method such as Kissinger-AkahiraSunose (KAS) has gained a great attention to get accurate results of pyrolysis and gasification kinetic analysis (pre-exponential factor $\left(\mathrm{K}_{\mathrm{o}}\right)$ and activation energy $\left.\left(E_{a}\right)\right) .{ }^{15}$ Additionally, the method has a capability to determine kinetic parameters exclusive of computing $E_{a}$ for each conversion value. ${ }^{16}$ Currently, model free fitting method has been extensively used to examine the thermal degradation of various types of biomasses such as ramie residue, ${ }^{17}$ sawdust,,${ }^{17}$ cotton, ${ }^{17}$ poplar wood ${ }^{18}$ and chlorella vulgaris. ${ }^{9}$

Thus, a series of non-isothermal experiments were carried out using model free fitting approach, where the weight of NG biomass samples was quantified as a function of temperature. Arrhenius equation is employed to determine the rate constant $A$ with respect to temperature $T$, as given below: ${ }^{9,19}$

$$
K=A_{\mathrm{o}} \exp \left(-\frac{E_{a}}{R T}\right)
$$

where, $A_{\circ}$ is pre-exponential factor $(1 / \mathrm{min}), E_{a}$ is activation energy $(\mathrm{kJ} / \mathrm{mol}), R$ is $8.314(\mathrm{~K} / \mathrm{J} / \mathrm{mol})$ and $T$ is the temperature.

Non-isothermal route can be categorised using constant heating rate $(\beta)$. Therefore, the relationship between $T$ and $\beta$ of the NG biomass can be written as:

$$
T=T_{i}+\beta_{t}
$$

where, $T_{i}$ is the initial temperature and $T$ is the reaction zone temperature..$^{20,21}$ 
Thus, the $E_{a}$ was calculated from Kissinger-Akahira-Sunose (KAS) method based on following equations: ${ }^{19}$

$$
\begin{aligned}
& \ln \left(\frac{\beta}{T_{P}^{2}}\right)=\frac{-E_{a}}{R T_{P}}+\ln \frac{A_{\mathrm{o}} E_{a}}{R} \\
& \ln \beta=\frac{-E_{a}}{R T_{P}}+\ln \frac{A_{\mathrm{o}} E_{a}}{R}
\end{aligned}
$$

where, $T_{p}$ is the peak zone degradation temperature of NG sample and the $\beta$ can be stated as:

$$
\beta=\frac{d T}{d t}
$$

Therefore, $E_{a}$ at distinctive zones from TG-DTG thermogram can be determined by plotting $\ln \left(\frac{\beta}{T_{p}^{2}}\right)$ vs. $\frac{10^{3}}{T_{p}}$.

\section{RESULTS AND DISCUSSION}

\subsection{Proximate Analysis}

The characterisation of NG biomass as a potential energy source has been taken into consideration in the current study. Table 1 shows the proximate analysis of NG biomass at different heating rates using dissimilar atmospheres. In this study, three different heating rates are used, which are $5^{\circ} \mathrm{C} / \mathrm{min}, 10^{\circ} \mathrm{C} / \mathrm{min}$ and $20^{\circ} \mathrm{C} / \mathrm{min}$ (not replicated) to reach targeted temperature of $1,000^{\circ} \mathrm{C}$ under air and $\mathrm{N}_{2}$ atmospheres. Since the trend at all heating rates was almost same with different atmospheric conditions, respectively, the results acquired at $10^{\circ} \mathrm{C} / \mathrm{min}$ were taken into consideration for further explanation. However, the variations of $5^{\circ} \mathrm{C} / \mathrm{min}$ and $20^{\circ} \mathrm{C} / \mathrm{min}$ heating rate can be observed from Table 1 .

Figure 1 illustrates the proximate analysis variations due to different in atmospheres $\left(\mathrm{N}_{2}\right.$ and air) at $10^{\circ} \mathrm{C} / \mathrm{min}$ heating rate. NG biomass in air atmosphere provided marginally higher moisture content of $8.78 \%$ compared to the biomass in $\mathrm{N}_{2}$ atmosphere $(7.73 \%)$. The higher moisture contents in air atmosphere is due to the presence of oxygen in air which promotes biomass devolatilisation. ${ }^{9}$ Biomass moisture content varies considerably depending on the type of feedstock and its storage or handling. The presence of moisture content in the biomass is of great significance in order to select the biomass conversion technology. The fuel from 
Table 1: Proximate analysis of NG biomass under air and nitrogen atmospheres and varying heating rates.

\begin{tabular}{|c|c|c|c|c|c|c|c|c|c|}
\hline & \multicolumn{6}{|c|}{ Present study } & \multicolumn{3}{|c|}{ Literatures } \\
\hline & \multicolumn{3}{|c|}{ Air atmosphere, $(\%)$} & \multicolumn{3}{|c|}{$\mathrm{N}_{2}$ atmosphere, $(\%)$} & \multirow{2}{*}{$\begin{array}{c}\text { Napier grass }^{26} \\
-\end{array}$} & \multirow{2}{*}{$\begin{array}{c}\text { Cardoon }^{27} \\
-\end{array}$} & \multirow{2}{*}{$\begin{array}{c}\text { Cardoon }^{28} \\
-\end{array}$} \\
\hline HR & 5 & 10 & 20 & 5 & 10 & 20 & & & \\
\hline M & 6.90 & 8.78 & 7.19 & 4.91 & 7.73 & 5.42 & 9.43 & 12.00 & - \\
\hline V & 82.05 & 81.49 & 86.83 & 65.25 & 62.70 & 56.82 & 72.58 & 76.02 & 64.70 \\
\hline $\mathrm{FC}$ & 3.83 & 3.54 & 1.93 & 15.63 & 9.69 & 16.17 & 8.35 & 9.19 & 17.40 \\
\hline A & 7.22 & 6.17 & 4.04 & 14.21 & 18.87 & 21.59 & 9.68 & 14.80 & 17.90 \\
\hline
\end{tabular}

HR: Heating rate; M: Moisture content; V: Volatile matters; FC: Fixed carbon; A: ash

biomass with lower moisture content is more appropriate for thermochemical conversion technology, whereas those with higher moisture content are suitable for biochemical conversion technology such as fermentation. ${ }^{22}$ In addition, according to Sheth and Babu, high moisture content of biomass tends to decrease the gasification performances as higher energy input is required during the drying process. ${ }^{23}$ Thus, the NG biomass with moisture content of $8.78 \%$ appears to be a potential candidate for direct thermochemical conversion.

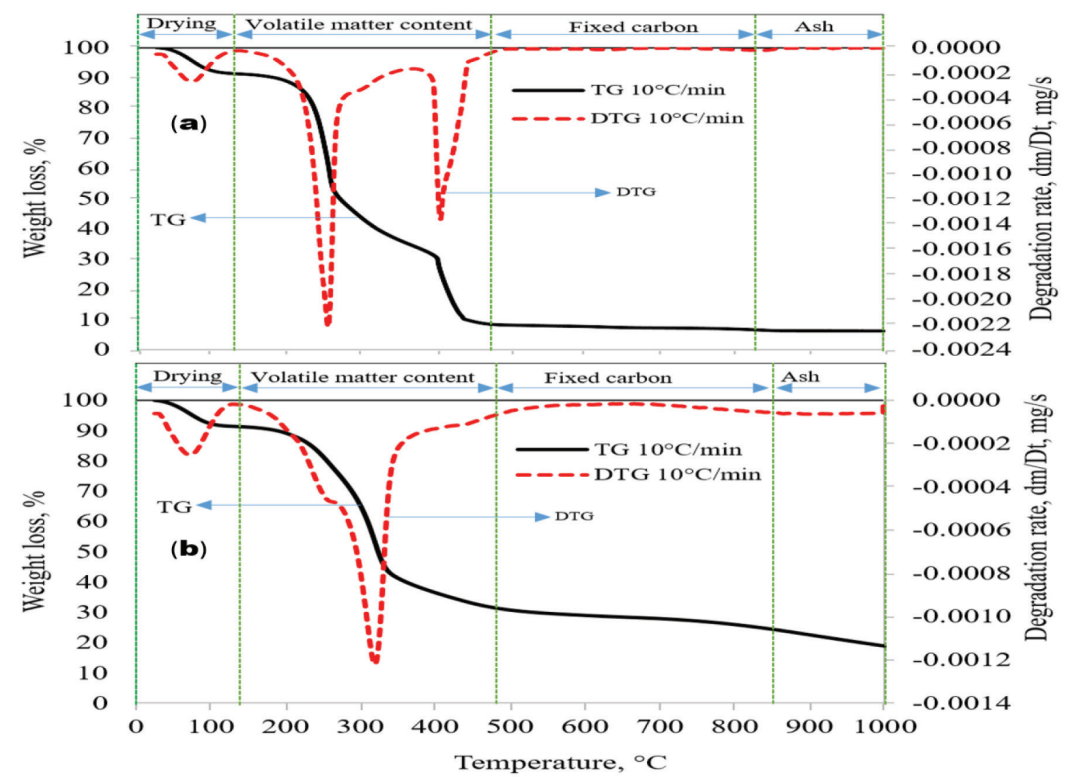

Figure 1: Proximate analysis of $\mathrm{NG}$ biomass in air (a) and $\mathrm{N}_{2}$ (b) atmospheres under $10^{\circ} \mathrm{C} / \mathrm{min}$ at a constant flow rate $25 \mathrm{~mL} / \mathrm{min}$ by TGA analyser. 
A similar trend for volatile matter content of NG biomass was noticed higher $(81.49 \%)$ in air atmosphere compared to nitrogen atmosphere $(62.70 \%)$. The high volatile matter in NG biomass strongly influences its combustion behaviour and thermal decomposition. Demirbas stated that high volatile matter content in biomass signifies high volatility and reactivity, which is essential for synthesis gas production. ${ }^{24}$ In contrast, the lower fixed carbon was found to be $(3.54 \%)$ in air atmosphere compared to the $\mathrm{N}_{2}$ atmosphere (9.69\%).

Moreover, ash content of roughly three times higher quantity was acquired under nitrogen as compared to air atmosphere. Ash content of biomass influences both the handling and managing costs of total biomass energy conversion. Additionally, the higher ash content in $\mathrm{N}_{2}$ atmosphere compared to air is noteworthy as it has negative effect on the heating value of biomass. ${ }^{25}$

From Table 1, it can be seen that the NG sample (air atmosphere) has low moisture content, high percentages of volatile matter, lower amount of fixed carbon followed by ash content as compared to other energy grasses, napier grass and cardoon in literature. ${ }^{26,27,28}$ Figure 1 shows that biomass cellular water removal, devolatilisation of volatile matter and fixed carbon followed ash content appeared at temperatures of $25^{\circ} \mathrm{C}-130^{\circ} \mathrm{C}, 130^{\circ} \mathrm{C}-470^{\circ} \mathrm{C}$ and $470^{\circ} \mathrm{C}-840^{\circ} \mathrm{C}$ in the existence of air, while a decelerating mass loss was seen in the $\mathrm{N}_{2}$ atmosphere under temperatures $23^{\circ} \mathrm{C}-135^{\circ} \mathrm{C}, 135^{\circ} \mathrm{C}-480^{\circ} \mathrm{C}$ and $480^{\circ} \mathrm{C}-850^{\circ} \mathrm{C}$ for water removal, devolatilisation of volatile matter and fixed carbon. The presence of oxygen in the air promotes biomass devolatilisation, thus higher volatile matters achieved compared to $\mathrm{N}_{2}$ atmosphere.

\subsection{Ultimate Analysis}

The result of the ultimate analyses of NG is shown in Table 2 . The ultimate analysis of NG showed percentages of oxygen $(48.52 \%)$, carbon $(45.10 \%)$, hydrogen $(6.50 \%)$, nitrogen $(0.45 \%)$, and sulphur content $(0.00 \%)$. According to C-atom, the molecular formula of NG biomass was determined to be $\mathrm{CH}_{1.58} \mathrm{O}_{0.81}$ based on abovementioned result (e.g., main elements $\mathrm{C}, \mathrm{H}$ and $\mathrm{O}$ ). These results were found to be comparable to other energy grasses in literature such as $\mathrm{NG},{ }^{26}$ cardoon $^{28}$ and Miscanthus..$^{28}$ On the other hand, in comparison to $\mathrm{NG}^{26}$ and cardoon, ${ }^{28} \mathrm{NG}$ (this study) has the highest oxygen and lowest carbon contents. This has a significant negative effect on the HHV of biomass due to the carbon-oxygen bonds. ${ }^{29}$ The HHV of NG $\left(16.73 \mathrm{MJ} / \mathrm{kg}\right.$ ) was higher than cardoon ${ }^{28}$ and slightly lower than cardoon ${ }^{22}$ and Miscanthus. ${ }^{23}$ Although the NG has moderate HHV, it still can be a potential alternative feedstock for energy generation based on its desirable characteristics such as high volatile matter and high biomass yield production. 
Table 2: Comparison of ultimate analysis results with other perennial energy crops in literature.

\begin{tabular}{lccccc}
\hline Composition (\%) & $\mathrm{NG}$ & $\mathrm{NG}^{26}$ & Cardoon $^{27}$ & Cardoon $^{28}$ & Miscanthus $^{28}$ \\
\hline $\mathrm{C}$ & 45.10 & 42.40 & 56.01 & 44.10 & 49.70 \\
$\mathrm{H}$ & 5.94 & 5.96 & 6.46 & 4.80 & 4.40 \\
$\mathrm{~N}$ & 0.45 & 1.71 & 0.99 & 2.00 & 0.20 \\
$\mathrm{~S}$ & - & 0.09 & 0.22 & 0.20 & - \\
O (by difference) & 48.52 & 45.32 & 36.10 & 31.50 & 41.30 \\
HHV $(\mathrm{MJ} / \mathrm{kg})$ & 16.73 & $\mathrm{NA}$ & 17.33 & 14.70 & 17.20 \\
\hline
\end{tabular}

NA: Not available

\subsection{Thermal Decomposition Characteristics}

TGA weight-loss curve and DTG analysis curves of NG samples under different heating rates $\left(5^{\circ} \mathrm{C} / \mathrm{min}, 10^{\circ} \mathrm{C} / \mathrm{min}\right.$ and $\left.20^{\circ} \mathrm{C} / \mathrm{min}\right)$ and atmosphere condition $\left(\mathrm{N}_{2}\right.$ and air) are shown in Figure 2. According to the shape of TG-DTG curves, a similar trend was found under air and $\mathrm{N}_{2}$ atmospheres for different heating rates. Thus, only the $10^{\circ} \mathrm{C} / \mathrm{min}$ heating rate was used to discuss thermal decomposition of NG sample under both atmospheres $\left(\mathrm{N}_{2}\right.$ and air). First, at temperature below $90^{\circ} \mathrm{C}$ in initial stage for both atmospheres, a low peak intensity was observed in all the DTG curves and this might represent the moisture removal. Furthermore, only a slightly weight loss of approximately of $4.28 \%$ (air) and $4.43 \%\left(\mathrm{~N}_{2}\right)$ were obtained in this stage. Three main stages, hemi-cellulose (zone I), cellulose (zone II) and lignin (zone III) regions of decomposition could be distinguished in Figure 2. As shown in Table 3, two noticeable DTG peaks were obtained with remarkable weight loss which were about $38 \%$ and $74 \%$ of weight loss in zone I and II at temperature of $254.83^{\circ} \mathrm{C}$ and $405.67^{\circ} \mathrm{C}$, respectively in air atmosphere. This weight loss could be due to the devolatilisation of light and heavy volatile compounds in the sample.

However, only one sharper DTG peak occurred in zone I and was about $47 \%$ of weight loss at temperature of $319^{\circ} \mathrm{C}$ in $\mathrm{N}_{2}$ atmospheres. This could be explained that oxygen in air enhances biomass devolatilisation. According to Lapuerta et al., ${ }^{30}$ this stage represents the decomposition hemicelluloses and cellulose. Demirbas and $\mathrm{Arin}^{25}$ stated that hemicelluloses usually starts to decompose at a lower temperature, while cellulose starts to decompose at a high temperature. Moreover, it was further observed that in zone III in air atmosphere, the TGA curves started to flatten slowly after temperature $570^{\circ} \mathrm{C}$. In contrast, in the tailing section of TGA in $\mathrm{N}_{2}$ atmosphere, it began to flatten slowly after $637^{\circ} \mathrm{C}$. This phenomenon can be explained that, after first two stages, the NG sample maintained some carbon, 
mental ions, tar, etc., which were stable and not easily decomposed. ${ }^{14}$ In addition, the lignin has good resistance to thermal degradation and is harder to decompose than cellulose since lignin contains benzene rings. ${ }^{31}$
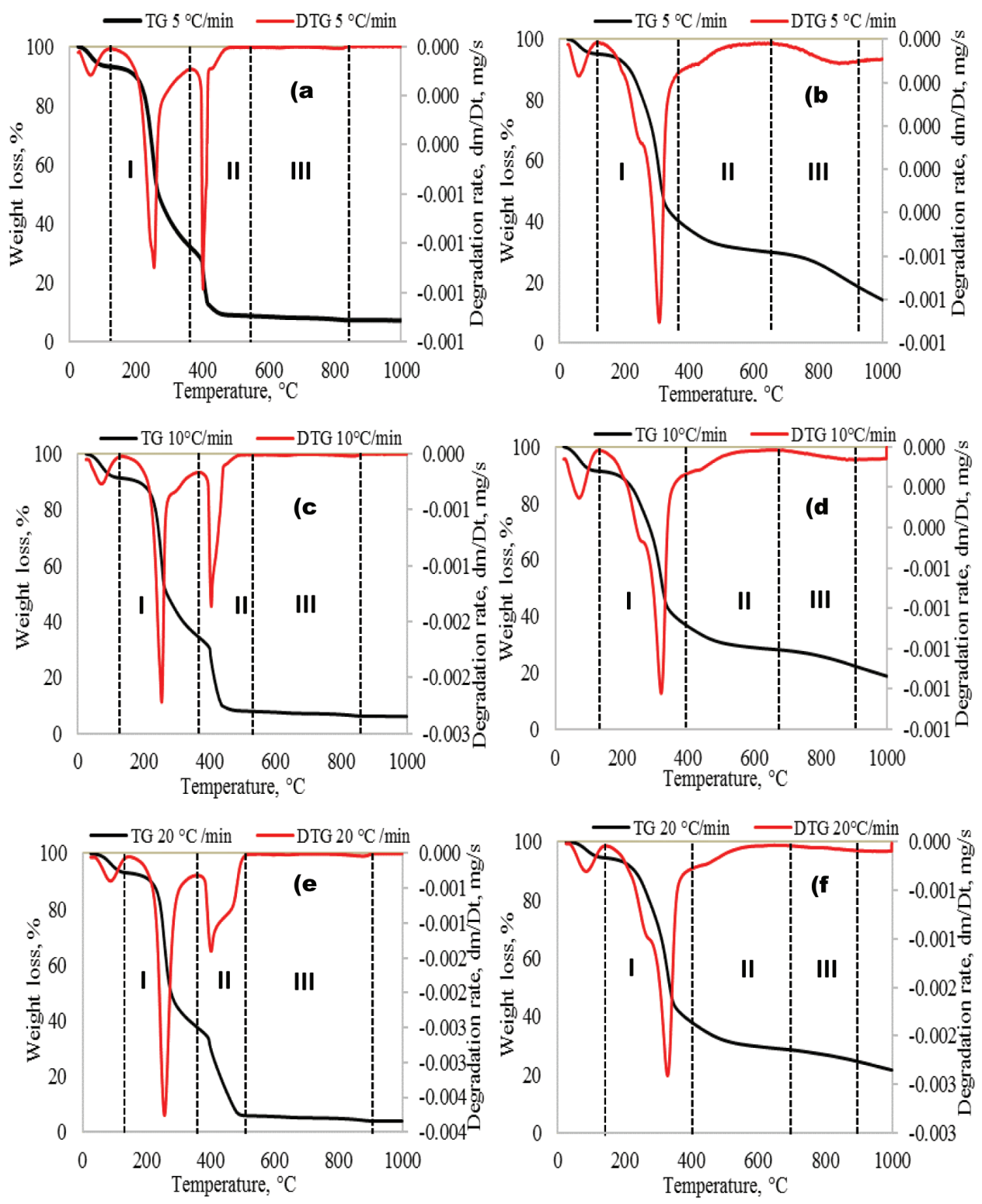

Figure 2: TG-DTG profile of NG biomass at different heating rates under air (a, c, e) and nitrogen $(b, d, f)$. 
Furthermore, as shown in Figure 2 and Table 3, the effect of heating rates on the thermal decomposition rate can be observed. Both TGA and DTG curves slightly shifted to higher temperature as the heating rates increased. The initial temperature $T_{i}$, the first DTG peak temperature $\left(T_{1}\right)$ and the second DTG peak temperature $\left(T_{2}\right)$ increased as the heating rates increased in the air and $\mathrm{N}_{2}$ atmospheres. For the air atmosphere, $\mathrm{T}_{\mathrm{i}}$ increased from $61.82^{\circ} \mathrm{C}$ to $87^{\circ} \mathrm{C}, \mathrm{T}_{1}$ increased from $254.42^{\circ} \mathrm{C}$ to $256^{\circ} \mathrm{C}$, and $\mathrm{T}_{2}$ increased from $401.83^{\circ} \mathrm{C}$ to $402.87^{\circ} \mathrm{C}$ as the heating rate increased. For the $\mathrm{N}_{2}$ atmosphere, $\mathrm{T}_{\mathrm{i}}$ increased from $59.25^{\circ} \mathrm{C}$ to $85^{\circ} \mathrm{C}$, and $\mathrm{T}_{1}$ increased from $308.33^{\circ} \mathrm{C}$ to $328.33^{\circ} \mathrm{C}$ as heating rate increased. Mohammed et al. and Li et al. have found similar results for oil palm empty fruit bunches gasification and corn straw pyrolysis, respectively. ${ }^{32,33}$ Higher heating rate could shorten the reaction time in the same temperature region, thus the sample required higher temperature to decompose. ${ }^{32}$ This phenomenon was revealed with the DTG peak curve slightly shifting to the right.

Table 3: Reaction regions and peak of NG samples at different heating rates.

\begin{tabular}{|c|c|c|c|c|c|c|c|c|c|c|}
\hline \multirow{2}{*}{$\begin{array}{l}\text { Atmosphere } \\
\text { conditions }\end{array}$} & \multirow{2}{*}{$\begin{array}{l}\text { Heating } \\
\text { rates } \\
\left({ }^{\circ} \mathrm{C} / \mathrm{min}\right)\end{array}$} & \multicolumn{3}{|c|}{ Temperature range $\left({ }^{\circ} \mathrm{C}\right)$} & \multicolumn{6}{|c|}{ The peak values of the DTG curve } \\
\hline & & Zone 1 & Zone 2 & Zone 3 & $\mathrm{~T}_{\mathrm{i}}\left({ }^{\circ} \mathrm{C}\right)$ & $\mathrm{T}_{1}\left({ }^{\circ} \mathrm{C}\right)$ & $\mathrm{T}_{2}\left({ }^{\circ} \mathrm{C}\right)$ & $\mathrm{W}_{\mathrm{i}}(\%)$ & $\mathrm{W}_{1}(\%)$ & $\mathrm{W}_{2}(\%)$ \\
\hline \multirow[t]{3}{*}{ Air } & 5 & $119-366$ & $366-570$ & $570-840$ & 61.82 & 254.42 & 401.83 & 3.04 & 40.40 & 76.12 \\
\hline & 10 & $136-367$ & $367-570$ & $570-862$ & 72.00 & 254.83 & 402.20 & 4.28 & 38.42 & 74.02 \\
\hline & 20 & $144-358$ & $358-553$ & $553-923$ & 87.00 & 256.00 & 402.87 & 3.56 & 32.55 & 70.50 \\
\hline \multirow[t]{3}{*}{$\mathrm{N}_{2}$} & 5 & $113-393$ & $393-628$ & $628-973$ & 59.25 & 308.33 & - & 2.05 & 43.83 & - \\
\hline & 10 & $130-400$ & $400-637$ & $637-971$ & 72.00 & 319.00 & - & 4.43 & 46.77 & - \\
\hline & 20 & $144-406$ & $406-650$ & $650-914$ & 85.00 & 328.33 & - & 2.58 & 44.73 & - \\
\hline
\end{tabular}

$T_{i}$ : Initial temperature (moisture removal); $T_{1}:$ Temperature of the second peak of the DTG curve; $T_{2}:$ Temperature of the third peak of the DTG curve; $W_{i}$ : Weight loss in the moisture removal region; $W_{1}$ : Weight loss in the first peak of the DTG curve; $W_{2}$ : Weight loss in the second peak of the DTG curve.

\section{Kinetic Analysis}

The TG-DTG experimental data of gasification process was incorporated to the model free fitting method for analysing the distinct constituents of feedstock as distinguished in the DTG profile in Figure 2. In the study, the activation energy $\left(E_{a}\right)$ and pre-exponential factor $\left(\mathrm{K}_{\mathrm{o}}\right)$ values were verified through the KAS method by charting $\ln \beta / \mathrm{T}^{2}{ }_{\mathrm{p}}$ Vs. $10^{3} / \mathrm{T}_{\mathrm{p}}$, which makes a straight line as shown in Figure 3 . The three zone temperatures corresponding to the distinctive heating rates and kinetic parameters such as activation energy, pre-exponential factor, slope and intercept are shown in Table 4. The zones represent decomposition of extractives, hemicellulose, cellulose and lignin. ${ }^{7}$ 
The correlation co-efficients $\left(R^{2}\right)$ obtained were 1 (zone I), 0.96 (zone II) and 0.97 (zone III), which justify the model accuracy and data. Figure 3 shows the $-\mathrm{E}_{\mathrm{a}} / \mathrm{R}$ (slope) values from the zone I, zone II, and zone III which were -4.927 , -8.644 , and -12.865 , respectively. With the gas coefficient $\mathrm{R}=8.314 \mathrm{~J} / \mathrm{K} / \mathrm{mol}$, the estimated $\mathrm{E}_{\mathrm{a}}$ values were 40.96, 71.87 and $106 \mathrm{~kJ} / \mathrm{mol}$. The degree of weight loss during the gasification process is dependent on its compositional structure such as hemicellulose, cellulose and lignin and the required $\mathrm{E}_{\mathrm{a}}$ may vary with temperature and heating rate. ${ }^{34,35}$

The obtained activation energy values in the present study are compared with other perennial energy crops in literature in Table 5.28 The activation energy values from the present study were lower than miscanthus and higher than C. vulgaris and cardoon. In general, it is difficult to compare activation energy of biomass due to different operating condition such as heating rate and type of flow medium, biomass characteristics as well as different kinetic methods. ${ }^{13}$ Thus, in order to better understand about the activation energy with other biomasses, the same kinetic model applied in study should be chosen.

\section{Zone I Zone II $\triangle$ Zone III}

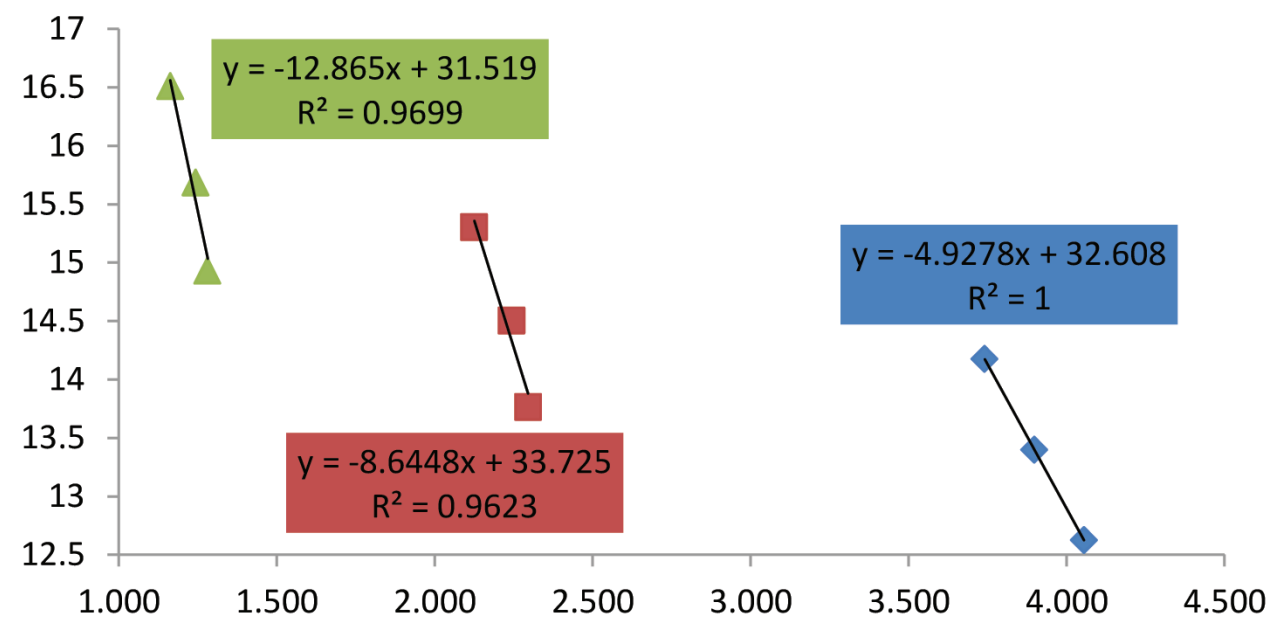

Figure 3: Kissinger plot of activation energy in the air atmosphere for I, II, and III decomposition zone temperatures at three heating rates $\left(5^{\circ} \mathrm{C} / \mathrm{min}, 10^{\circ} \mathrm{C} / \mathrm{min}\right.$ and $20^{\circ} \mathrm{C} / \mathrm{min}$ ). 
Table 4: Activation energy of NG biomass calculated from TG-DTG for three varied heating rates.

\begin{tabular}{|c|c|c|c|c|c|c|c|c|c|}
\hline \multirow{2}{*}{$\begin{array}{l}\text { Specifications } \\
\text { Heating rate, } \\
\beta\left({ }^{\circ} \mathrm{C} / \mathrm{min}\right)\end{array}$} & \multicolumn{3}{|c|}{ Zone I } & \multicolumn{3}{|c|}{ Zone II } & \multicolumn{3}{|c|}{ Zone III } \\
\hline & 5 & 10 & 20 & 5 & 10 & 20 & 5 & 10 & 20 \\
\hline $\begin{array}{l}\text { Temperature } \\
\text { max. peak, Tmax }\left({ }^{\circ} \mathrm{C}\right)\end{array}$ & 246.6 & 256.5 & 267.3 & 435.6 & 445.8 & 470.6 & 780.4 & 804.5 & 860 \\
\hline $\begin{array}{l}\text { Activation energy, } \mathrm{E}_{\mathrm{a}} \\
(\mathrm{kJ} / \mathrm{mol})\end{array}$ & \multicolumn{3}{|c|}{40.96} & \multicolumn{3}{|c|}{71.87} & \multicolumn{3}{|c|}{106.95} \\
\hline $\begin{array}{l}\text { Pre-exponential } \\
\text { Factor, } \mathrm{K}_{0}(1 / \mathrm{min})\end{array}$ & \multicolumn{3}{|c|}{$2.943 \times 10^{13}$} & \multicolumn{3}{|c|}{$5.128 \times 10^{13}$} & \multicolumn{3}{|c|}{$3.793 \times 10^{12}$} \\
\hline $\mathrm{R}^{2}$ & \multicolumn{3}{|c|}{1} & \multicolumn{3}{|c|}{0.9623} & \multicolumn{3}{|c|}{0.9699} \\
\hline Slope $\left(-E_{a} / R\right)$ & \multicolumn{3}{|c|}{-4.9278} & \multicolumn{3}{|c|}{-8.6448} & \multicolumn{3}{|c|}{-12.865} \\
\hline Intercept & \multicolumn{3}{|c|}{32.608} & \multicolumn{3}{|c|}{33.725} & \multicolumn{3}{|c|}{31.519} \\
\hline
\end{tabular}

Table 5: Comparison of kinetic parameters at various operating conditions for different perennial energy crops.

\begin{tabular}{|c|c|c|c|c|c|c|}
\hline \multirow[b]{2}{*}{ Species } & \multicolumn{3}{|c|}{ Operating parameters } & \multirow[b]{2}{*}{ Method } & \multirow{2}{*}{$\begin{array}{c}\text { Activation } \\
\text { energy, } \mathrm{E}_{\mathrm{a}} \\
(\mathrm{kJ} / \mathrm{mol})\end{array}$} & \multirow[b]{2}{*}{ Reference } \\
\hline & $\begin{array}{l}\text { Heating rate } \\
\left({ }^{\circ} \mathrm{C} / \mathrm{min}\right)\end{array}$ & $\begin{array}{c}\text { Temperature } \\
\left({ }^{\circ} \mathrm{C}\right)\end{array}$ & $\begin{array}{l}\text { Atmosphere } \\
(\mathrm{mL} / \mathrm{min})\end{array}$ & & & \\
\hline NG & $5-20$ & A-1000 & $\mathrm{N}_{2} /$ air (25) & KAS & $40.96-106.95$ & Current study \\
\hline C. vulgaris & $5-20$ & $\mathrm{~A}-1000$ & $\mathrm{~N}_{2} / \operatorname{air}(25)$ & KAS & $45.38-97.22$ & 9 \\
\hline Cardoon & 10 & A-950 & $\operatorname{Ar}(35)$ & $\begin{array}{l}\text { First order } \\
\text { parallel }\end{array}$ & $24.40-103.70$ & 28 \\
\hline Miscanthus & 10 & A-950 & $\operatorname{Ar}(35)$ & $\begin{array}{c}\text { First order } \\
\text { parallel }\end{array}$ & $\begin{array}{l}28.90- \\
138.0\end{array}$ & 28 \\
\hline
\end{tabular}

A: Ambient temperature

\section{CONCLUSION}

The thermal decomposition characteristics, reactivity and kinetic of NG was characterised by TGA under inert $\left(\mathrm{N}_{2}\right)$ and air atmosphere conditions, respectively. Proximate and ultimate analyses revealed that the NG biomass has moderate HHV, low moisture content, high volatile matter contents and lower nitrogen and sulphur contents. In addition, NG can also produce high biomass yield per annum. The activation energy values, based on the Kissinger method, were evaluated to be $40.96 \mathrm{~kJ} / \mathrm{mol}$ (zone 1), $71.87 \mathrm{~kJ} / \mathrm{mol}$ (zone 2) and $106.95 \mathrm{~kJ} / \mathrm{mol}$ (zone 3) which 
is higher than C. vulgaris and cardoon. Thus, based on abovementioned, NG biomass can be a more promising candidate for syngas production via gasification technology.

\section{ACKNOWLEDGEMENTS}

The authors would like to acknowledge the financial support from the Ministry of Higher Education (MOHE) Malaysia via LRGS grant (LRGS/2013/UKM/PT) and Crop for Future (CFF) for providing feedstock materials for this work.

\section{REFERENCES}

1. Hosseini, S.E. \& Wahid, M. A. (2013). Feasibility study of biogas production and utilization as a source of renewable energy in Malaysia. Renew. Sustain. Energy Rev., 19, 454-462, http://dx.doi.org/10.1016/j.rser.2012.11.008.

2. Gan, P. Y. \& Li, Z. (2008). An econometric study on long-term energy outlook and the implications of renewable energy utilization in Malaysia. Energy Policy, 36(2), 890-899, https://doi.org/10.1016/j.enpol.2007.11.003.

3. Ahmad, S. \& Tahar, R. M. (2014). Selection of renewable energy sources for sustainable development of electricity generation system using analytic hierarchy process: A case of Malaysia. Renew. Energy, 63, 458-466, http://dx.doi.org/10.1016/j.renene.2013.10.001.

4. Hlavsová, A. et al. (2014). Syngas production from pyrolysis of nine composts obtained from nonhybrid and hybrid perennial grasses. Sci. World $J$., Article ID 72309, http://dx.doi.org/10.1155/2014/723092.

5. De Conto, D. et al. (2016). Performance of rotary kiln reactor for the elephant grass pyrolysis. Biores. Technol., 218, 153-160, https://dx.doi.org/10.1016/j. biortech.2016.06.082.

6. Woodard, K. \& Prine, G. (1993). Dry matter accumulation of elephantgrass, energycane, and elephantmillet in a subtropical climate. Crop Sci., 33(4), 818-824, https://doi.org/10.2135/cropsci1993.0011183X003300040038x.

7. Mohammed, I. Y. et al. (2015). Comprehensive characterization of napier grass as a feedstock for thermochemical conversion. Energies, 8(5), 34033417, http://dx.doi.org/10.3390/en8053403.

8. Moghadam, R. A. et al. (2014). Investigation on syngas production via biomass conversion through the integration of pyrolysis and air-steam gasification processes. Energy Conv. Manage., 87, 670-675, http://dx.doi. org/10.1016/j.enconman.2014.07.065. 
9. Raheem, A. et al. (2015). Thermogravimetric study of Chlorella vulgaris for syngas production. Algal Res., 12, 52-59, http://doi.org/10.1016/j.algal. 2015.08.003.

10. Xue, G. et al. (2014). Gasification of Miscanthus $\mathrm{x}$ giganteus in an airblown bubbling fluidized bed: a preliminary study of performance and agglomeration. Energy Fuels, 28(2), 1121-1131, https://doi.org/10.1021/ ef4022152.

11. Shen, D. et al. (2009). Kinetic study on thermal decomposition of woods in oxidative environment. Fuel, 88(6), 1024-1030, http://dx.doi.org/10.1016/j. fuel.2008.10.034.

12. Quan, C., Li, A. \& Gao, N. (2009). Thermogravimetric analysis and kinetic study on large particles of printed circuit board wastes. Waste. Manage., 29(8), 2353-2360, https://dx.doi.org/10.1016/j.wasman.2009.03.020.

13. Kok, M. V. \& Özgür, E. (2013). Thermal analysis and kinetics of biomass samples. Fuel Process. Technol., 106, 739-743, http://dx.doi.org/10.1016/j. fuproc.2012.10.010.

14. Gao, W. et al. (2013). Kinetic study on pyrolysis of tobacco residues from the cigarette industry. Ind. Crops Prod., 44, 152-157, https://doi.org/10.1016/j. indcrop.2012.10.032.

15. Damartzis, T. et al. (2011). Thermal degradation studies and kinetic modeling of cardoon (Cynara cardunculus) pyrolysis using thermogravimetric analysis (TGA). Biores. Technol., 102(10), 6230-6238, https://doi.org/10.1016/j. biortech.2011.02.060.

16. Çepelioğullar, Ö., Haykırı-Açma, H. \& Yaman, S. (2016). Kinetic modelling of RDF pyrolysis: Model-fitting and model-free approaches. Waste Manage., 48, 275-284, https://dx.doi.org/10.1016/j.wasman.2015.11.027.

17. Wang, B. et al. (2013). Nitrogen removal of ramie stalk treated by acid wastewater combined with Clostridium thermocellum and the kinetic study of pyrolysis. Biores. Technol., 129, 1-6, https://dx.doi.org/10.1016/j. biortech.2012.11.045.

18. Slopiecka, K., Bartocci, P. \& Fantozzi, F. (2012). Thermogravimetric analysis and kinetic study of poplar wood pyrolysis. Appl. Energy, 97, 491497, https://doi.org/10.1016/j.apenergy.2011.12.056.

19. Fraczyk, A. (2011). The activation energy of primary crystallization of Fe95Si5 metallic glass. Tech. Sci., 14, 93-100.

20. Chen, C., Ma, X. \& Liu, K. (2011). Thermogravimetric analysis of microalgae combustion under different oxygen supply concentrations. Appl. Energy, 88(9), 3189-3196, https://doi.org/10.1016/j.apenergy.2011.03.003.

21. Gai, C. et al. (2013). Thermogravimetric and kinetic analysis of thermal decomposition characteristics of low-lipid microalgae. Biores. Technol., 150, 139-148, https://dx.doi.org/10.1016/j.biortech.2013.09.137. 
22. McKendry, P. (2002). Energy production from biomass (Part 1): Overview of biomass. Biores. Technol., 83(1), 37-46, http://dx.doi.org/10.1016/S09608524(01)00118-3.

23. Sheth, P. N. \& Babu, B. (2009). Experimental studies on producer gas generation from wood waste in a downdraft biomass gasifier. Biores. Technol., 100(12), 3127-3133, http://dx.doi.org/10.1016/j.biortech.2009.01.024.

24. Demirbas, A. (2004). Combustion characteristics of different biomass fuels. Progr. Energy Combust. Sci., 30(2), 219-230, http://dx.doi.org/10.1016/j. pecs.2003.10.004.

25. Demirbas, A. \& Arin, G. (2002). An overview of biomass pyrolysis. Energy Sour., 24(5), 471-482, http://dx.doi.org/10.1080/00908310252889979.

26. Lee, M.-K. et al. (2010). Pyrolysis of napier grass in an induction-heating reactor. J. Anal. Appl. Pyrol., 88(2), 110-116.

27. Karampinis, E. et al. (2012). Comparative study of combustion properties of five energy crops and Greek lignite. Energy Fuels, 26(2), 869-878, https://doi.org/10.1021/ef2014088.

28. Vamvuka, D. et al. (2016). Kinetic modeling of five sustainable energy crops as potential sources of bioenergy. Energy Sources A, 38(12), 1812-1818, http://dx.doi.org/10.1080/15567036.2014.1002949.

29. McKendry, P. (2002). Energy production from biomass (Part 2): Conversion technologies. Biores. Technol., 83(1), 47-54, http://dx.doi.org/10.1016/ S0960-8524(01)00119-5.

30. Lapuerta, M. N., Hernández, J. J. \& Rodríguez, J. N. (2004). Kinetics of devolatilisation of forestry wastes from thermogravimetric analysis. Biomass Bioenergy, 27(4), 385-391, http://dx.doi.org/10.1016/j.biombioe. 2003.11.010.

31. Sharma, R. K. et al. (2004). Characterization of chars from pyrolysis of lignin. Fuel, 83(11), 1469-1482, https://doi.org/10.1016/j.fuel.2003.11.015.

32. Mohammed, M. et al. (2012). Gasification of oil palm empty fruit bunches: A characterization and kinetic study. Biores. Technol., 110, 628-636, https://dx.doi.org/10.1016/j.biortech.2012.01.056.

33. Li, Z. et al. (2008). Kinetic study of corn straw pyrolysis: Comparison of two different three-pseudocomponent models. Biores. Technol., 99(16), 76167622, https://dx.doi.org/10.1016/j.biortech.2008.02.003.

34. Liu, Y.-Q. et al. (2012). Investigation on pyrolysis of microalgae Botryococcus braunii and Hapalosiphon sp. Ind. Eng. Chem. Res., 51(31), 10320-10326, https://doi.org/10.1021/ie202799e.

35. Liu, N. et al. (2002). Kinetic modeling of thermal decomposition of natural cellulosic materials in air atmosphere. J. Anal. Appl. Pyrol., 63(2), 303-325, https://doi.org/10.1016/S0165-2370(01)00161-9. 
